\title{
A North American System of Nomenclature for Puccinia coronata f. sp. avenae
}

\author{
J. Chong, Cereal Research Centre, Agriculture \& Agri-Food Canada, Winnipeg, MB, Canada R3T 2M9; K. J. \\ Leonard, United States Department of Agriculture, Agricultural Research Services, Cereal Disease Laboratory, \\ University of Minnesota, St. Paul 55108; and J. J. Salmeron, INIFAP-Campo Experimental Sierra de Chihuahua, \\ Cd. Cuauhtemoc, Chih., Mexico 31500
}

\begin{abstract}
Chong, J., Leonard, K. J., and Salmeron, J. J. 2000. A North American system of nomenclature for Puccinia coronata f. sp. avenae. Plant Dis. 84:580-585.

A nomenclature system for designating virulence phenotypes of Puccinia coronata f. sp. avenae, the causal agent of oat crown rust, is proposed. Sixteen single gene oat (Avena sativa) lines, with seedling resistance genes $P c 38,39,40,45,46,48,50,51,52,54,56,58,59,62,64$, and 68 , are the primary differentials. The host lines are arranged into groups of four (subset $1=$ $P c 40,45,46,50$; subset $2=P c 38,39,48,68$; subset $3=P c 51,52,58,59$; subset $4=P c 54,56$, 62, 64). Avirulence and virulence of Puccinia coronata f. sp. avenae isolates on each line are indicated by low and high infection types, respectively. A letter from the 16 consonants B through $\mathrm{T}$ is assigned to each of the 16 possible combinations of low and high infection types on the four differentials of each subset. Designations for $P$. coronata $\mathrm{f}$. sp. avenae virulence phenotypes are indicated by a four-letter code for the virulence combinations on all four subsets, one letter for each subset. Local differential series are separated from the four-letter code by a dash, followed by an additional letter code describing the virulence combinations of the isolates on the local supplemental differentials. When fewer than four differentials are used in the supplemental series, virulence combination on these differentials for each isolate is described by a listing of the $P c$ gene(s) to which the isolate was virulent, following the four-letter code and a dash. This nomenclature system for $P$. coronata $\mathrm{f}$. sp. avenae is similar to the nomenclature system in use for $P$. graminis f. sp. tritici and P. triticina.
\end{abstract}

Four distinct physiologic virulence phenotypes (races) of Puccinia coronata f. sp. avenae were first described by Hoerner in 1919 (20), based on infection levels on two oat cultivars, Ruakura Rust Proof and Green Russian. Physiologic specialization of the fungus was later confirmed by Popp in Canada (31) and Parson in the United States (29) using additional oat cultivars. Murphy and Peturson examined physiologic specialization of $P$. coronata with a differential set of 11 common oat cultivars (28,30), which included Sunrise, Belar, Red Rustproof, Sterisel, Ruakura Rustproof, Green Russian, Anthony, Hawkeye, Green Mountain, White Tartar, and Glabrota. With these differentials, Murphy

Corresponding author: J. Chong

E-mail: jchong@em.agr.ca

Contribution 1758, Agriculture and Agri-Food Canada.

Accepted for publication 2 February 2000.

Publication no. D-2000-0320-01S

This article is in the public domain and not copyrightable. It may be freely reprinted with customary crediting of the source. The American Phytopathological Society, 2000.
(28) identified 33 virulence phenotypes of $P$. coronata $\mathrm{f}$. sp. avenae in the United States, and Peturson (30) identified 11 virulence phenotypes from Canadian collections.

In the 1940s, resistance derived from cultivars Victoria (crown rust resistance genes $P c 2$ and $P c 11)$ and Bond $(P c 3$ and $P c 4)$ was important in North American oat breeding programs $(34,35)$. These two cultivars were added to the standard differential series. By the late 1940s, most of the 13 differential cultivars were susceptible to the prevalent virulence phenotypes. In 1952, Simons and Murphy (36) established a new standard set of 10 cultivars. Anthony, Victoria, and Bond were retained from the previous set, and Appler, Landhafer $(P c 5)$, Santa Fe $(P c 6, P c 7, P c 8$, $P c 9 c, P c 21)$, Ukraine $(P c 3 c, P c 4 c, P c 6 c$, $P c 9)$, Trispernia $(P c 6 d)$, Bondvic, and Saia (Pc15, Pc16, Pc17) were selected because they were important sources of resistance to crown rust at that time. By 1970, most of the 10 standard differentials in the second differential set were highly susceptible to the prevalent virulence phenotypes in North America (9).

Many new resistance genes were isolated from the wild relative Avena sterilis from 1960 to 1980 (9). Fleischmann and
Baker (9) proposed the use of a new set of differentials based on single resistance genes from A. sterilis backcrossed into the cultivar Pendek. This led to the use of 12 single-gene Pendek-backcross lines with crown rust resistance genes $P c 35, P c 38$, Pc39, Pc40, Pc45, Pc46, Pc47, Pc48, $P c 50, P c 54, P c 55$, and $P c 56$ as the new differential set (16). Avirulence-virulence formulae (15) were used to designate virulence combinations of $P$. coronata $\mathrm{f}$. sp. avenae isolates by listing all the effective and ineffective resistance genes and using a slash (/) to separate the two groups. The new differential set was designed to be open-ended, as differentials could be dropped or new resistance genes could be added to the set when these genes became available. In 1979, single-gene lines with Pc62 and Pc63 were added to the set when these genes were isolated and backcrossed to the cultivar Fraser (17). In 1982, the line with $P c 47$ was dropped, and single-gene lines containing the newly isolated genes Pc64, Pc67, and Pc68 from A. sterilis were added (18). In 1989, single-gene lines containing the crown rust resistance genes Pc58, Pc59, Pc60, and Pc61 from A. sterilis were added (6). In 1995, lines containing Pc55 and Pc67 were dropped from the differentials (7). Gene Pc55 was dropped because it is similar to $P c 39$ in response to Canadian $P$. coronata f. sp. avenae isolates; a low infection type is obtained on Pc55 only when infection type is also low on Pc39 (J. Chong, unpublished). The Pc67 differential was dropped because of its temperature sensitivity, changing from resistance to susceptibility at temperatures above $25^{\circ} \mathrm{C}$ (J. Chong, unpublished).

In North America, P. coronata f. sp. avenae is highly diverse in virulence phenotype, in part due to the prevalence of sexual reproduction $(5,22$; K. J. Leonard, unpublished). Selective changes in virulence phenotype frequencies have occurred in the $P$. coronata f. sp. avenae populations shortly after the introduction of the specific resistance genes in oat cultivars $(5,34)$. Regional gene deployment is being used as a strategy to extend the useful life of specific resistance genes (3). However, the lack of a standardized nomenclature system for describing virulence phenotypes of $P$. coronata f. sp. avenae has hindered 
communication among oat researchers. This paper describes a nomenclature system that should enhance communication among oat breeders and pathologists in North America and facilitate a better understanding of how virulences are selected in the North American crown rust populations. This new nomenclature system for $P$. coronata f. sp. avenae (Pca) is similar to the nomenclature system in use for $P$. graminis f. sp. tritici (32) and P. triticina (25).

\section{Host Differentials}

Sixteen single-gene oat lines with $P c 38$, $39,40,45,46,48,50,51,52,54,56,58$, $59,62,64$, or 68 were selected as differentials for use in this nomenclature system. These differential host genes were chosen on the following basis: (i) stability and clear distinction of low and high infection types (ITs) under the range of greenhouse conditions normally used for testing, (ii) differential response to the $P$. coronata $\mathrm{f}$. sp. avenae populations in North America, and (iii) importance in breeding for resistance or in studies of virulence. Low ITs were 0,1 , and 2 , which indicate host resistance, and high ITs were 3 and 4, which indicate susceptibility (28). The 16 differential host genes produce a range of typical ITs (Table 1). The cultivars Makuru, Marvellous, or Starter are being used as susceptible checks to determine a high IT.

Resistance genes Pc40, Pc45, Pc46, $P c 50, P c 54$, and Pc56 were chosen as differentials because they distinguish $P$. coronata f. sp. avenae populations in North America in which frequency of virulence genes differs (5; J. Chong, unpublished; K. J. Leonard, unpublished). None of these genes are known to have been used in commercial oat cultivars grown in North America, yet regional differences in virulence frequencies to these genes exist, based on results from past (5) or recent annual crown rust surveys (7; J. Chong, unpublished; K. J. Leonard, unpublished). Generally, virulence frequencies to $P c 40$ and $P c 46$ were found to occur at low levels (e.g., below 12\% in 1995) in eastern Canada and Mexico but at moderate to high levels (between 18 to $100 \%$ in 1995) elsewhere in North America (Table 2). Virulence frequencies to $P c 56$ vary between low and moderate levels (between 11 and $47 \%$ ), depending on region in North America (Table 2), e.g., consistently occurring at lower levels in the Canadian prairie region than in eastern Canada (5). Virulence frequency to gene $P c 45$ is currently high only in Mexico (Table 2). Virulence frequency to Pc50 is very low in Canada and Mexico, but varies between low and moderate in different regions of the United States (Table 2). Virulence to Pc54 is very low in Canada but is more commonly detected in Mexico and regions 2, 3, and 4 of the United States (Table 2).

Resistance genes Pc38, Pc39, Pc48, Pc51, Pc52, Pc58, Pc59, and Pc68 were chosen as differentials, because these genes either represent important sources of resistance in current oat cultivars or are being used in oat breeding programs to develop crown rust resistant cultivars in North America. For instance, Pc38 and Pc39 are present in the commercial cultivars currently grown in Ontario and in the eastern prairie region (Manitoba and eastern Saskatchewan) of Canada, as well as in several of the cultivars currently grown in the midwestern United States. Cultivars with these two genes singly or combined were highly resistant to Canadian $P$. coro- nata f. sp. avenae isolates when they were first released in the early 1980s (5). Widespread use of cultivars with Pc38 and Pc39 has selected $P$. coronata f. sp. avenae virulence phenotypes with virulence to these genes. As a result, virulence frequency to Pc38 and Pc39 is high in Ontario and in the eastern prairie region (Manitoba and eastern Saskatchewan) of Canada, but is low or moderate in the different parts of the United States and Mexico (Table 2). Host resistance genes $P c 48$, Pc58, Pc59, Pc62, and Pc68 are being used in the Canadian breeding programs at

Table 1. Pedigrees of the 16 single-gene differential Avena sativa hosts, the $P c$ gene present in each of the differentials, and typical avirulent infection types produced when inoculated with Puccinia coronata f. sp. avenae

\begin{tabular}{llcc}
\hline $\boldsymbol{P c}$ gene & Pedigree or isoline & Typical low infection types $^{\text {a }}$ & Reference \\
\hline 38 & CAV $2648-4 / 4 *$ Pendek & $;$ to $; 1$ & 10 \\
39 & CAV 5165/4*Pendek & $;$ to $; 1$ & 10 \\
40 & Pendek*2/CAV 4997 & $; 1$ & 10 \\
45 & Pendek*4/CAV 5050 & $;$ & 11 \\
46 & Pendek*4/CAV 5115 & $;$ to $; 1$ & 11 \\
48 & Pendek*2/CAV 5041 & $;$ to ;1 & 12 \\
50 & CAV 2643/4*Pendek & 0 & 12 \\
51 & Iowa Early isoline X-434 & $;$ & 34 \\
52 & Iowa Midseason isoline X-421 & $; 1$ to ;2 & 34 \\
54 & Pendek*2/CAV 1832 & $; 1$ & 27 \\
56 & CAV 1964/4*Pendek & $;$ to $; 1$ & 31 \\
58 & TAM-O-301 (P.I. 295919) & $;$ & 34 \\
59 & TAM-O-312 (P.I. 296244) & $; 1$ to ;2 & 19 \\
62 & Fraser*4/CAV 4274 & 0 & 37 \\
64 & Makuru*2//CAV 4248/2*Sun II & 37 \\
68 & Makuru*2//CAV 4904/2*Sun II & & 34 \\
\hline
\end{tabular}

a Typical low infection types may vary slightly depending on pathogen genotype and environment. 0 = no uredinia or other macroscopic signs of infection. ; = no uredinia, but necrotic or chlorotic flecks. 1 = small uredinia surrounded by chlorosis or necrosis. $2=$ small to medium-size uredinia in chlorotic areas. $3=$ medium-size uredinia in chlorotic areas. $4=$ large uredinia without necrosis or chlorosis.

b Canadian Avena collection.

Table 2. Frequency (\%) and distribution of Puccinia coronata f. sp. avenae isolates virulent on differential lines of Avena sativa with single genes $(P c)$ for crown rust resistance in Canada and the United States in 1995 and in Mexico in 1994 and 1995

\begin{tabular}{|c|c|c|c|c|c|c|c|c|c|}
\hline \multirow{2}{*}{$\begin{array}{l}P c \text { gene } \\
\text { lines }^{b}\end{array}$} & \multirow[b]{2}{*}{ Mexico } & \multicolumn{6}{|c|}{ United States $^{\text {a }}$} & \multicolumn{2}{|c|}{ Canada } \\
\hline & & 1 & 2 & 3 & 4 & 5 & 6 & MB/SKc & Ontario \\
\hline Pc40 & 11 & 93 & 75 & 83 & 50 & 100 & 78 & 55 & 3 \\
\hline Pc45 & 89 & 6 & 7 & 0 & 11 & 24 & 8 & 0 & 1 \\
\hline Pc46 & 11 & 45 & 40 & 38 & 11 & 18 & 42 & 30 & 9 \\
\hline Pc50 & 0 & 42 & 20 & 28 & 11 & 6 & 15 & 4 & 0 \\
\hline Pc38 & 9 & 27 & 25 & 21 & 56 & 29 & 43 & 74 & 80 \\
\hline Pc39 & 6 & 27 & 12 & 10 & 39 & 6 & 31 & 76 & 85 \\
\hline Pc48 & 2 & 5 & 0 & 3 & 6 & 0 & 3 & 4 & 0 \\
\hline Pc68 & 0 & 0 & 3 & 3 & 6 & 0 & 3 & 0 & 0 \\
\hline Pc51 & 11 & 80 & 78 & 73 & 50 & 35 & 56 & 40 & 4 \\
\hline Pc52 & 2 & 3 & 0 & 3 & 0 & 0 & 3 & 4 & 0 \\
\hline Pc58 & 6 & 12 & 43 & 24 & 6 & 18 & 13 & 3 & 0 \\
\hline Pc59 & 28 & 26 & 71 & 45 & 39 & 41 & 30 & 25 & 3 \\
\hline Pc54 & 23 & 7 & 23 & 31 & 28 & 6 & 13 & 3 & 0 \\
\hline Pc56 & 11 & 42 & 23 & 28 & 33 & 18 & 47 & 18 & 32 \\
\hline Pc62 & 0 & 1 & 1 & 0 & 11 & 12 & 5 & 1 & 18 \\
\hline Pc64 & 11 & 6 & 10 & 0 & 6 & 12 & 8 & 3 & 7 \\
\hline $\begin{array}{l}\text { No. of } \\
\text { isolates }\end{array}$ & 47 & 100 & 77 & 29 & 18 & 17 & 119 & 189 & 71 \\
\hline
\end{tabular}

a Region 1 = Texas, Oklahoma; region 2 = Louisiana, Mississippi; region 3 = Alabama, Georgia, Florida, North Carolina; region 4 = Massachusetts, Pennsylvania; region 5 = Ohio, Illinois; region 6, Minnesota, Iowa, North Dakota, South Dakota.

b Arranged in four subsets (subset $1=P c 40,45,46,50$; subset $2=P c 38,39,48,68$; subset $3=P c 51$, 52, 58, 59; subset $4=P c 54,56,62,64)$.

c Manitoba and eastern Saskatchewan.

-

Plant Disease / May 2000 
the Cereal Research Centre (CRC) in Winnipeg, Manitoba, Lacombe Research Center in Lacombe, Alberta, and the Eastern Cereal and Oilseed Research Centre in Ottawa, Ontario. The recently released cultihave resistance genes $P c 38, P c 39$, and $P c 68$. Frequency of virulences to $P c 48, P c 58$, Pc59, Pc62, and Pc68 currently are low in eastern and/or western Canada (Table 2) (7). Because of the value of these genes to breeding resistant oat cultivars in Canada, inclusion of these genes as differentials would be useful for detection of isolates with virulence to these genes.

Genes $P c 51$ and $P c 52$ have been used in Iowa multiline series $(13,14,35)$. Virulence frequency to $P c 51$ generally is moderate to high in the United States and in the eastern prairie region of Canada, but is very low in eastern Canada and Mexico (Table 2) (J. Chong, unpublished; K. J. Leonard, unpublished). Virulence to Pc52 is at low frequencies in all regions of North America, including Mexico (Table 2) (J. Chong, unpublished; K. J. Leonard, unpublished). Resistance genes Pc58 and Pc59 have been used in commercially grown cultivars in the southern and southeastern United States (35), and isolates with virulence to these genes have been common in these regions (K. J. Leonard, unpublished).

\section{Nomenclature for Virulence Phenotypes}

The new system of nomenclature for $P$. coronata $\mathrm{f}$. sp. avenae reported in this paper was adapted from the available systems in use for $P$. graminis f. sp. tritici (32) and $P$. triticina (25). The 16 host differentials were arranged in subsets of four using the vars, AC Assiniboia and AC Medallion,

following arrangement (Table 3). The first four differential hosts in subset 1 (Pc40, $P c 45, P c 46, P c 50)$ represent genes that are important in differentiating $P$. coronata $\mathrm{f}$. sp. avenae populations in North America due to regional differences in virulence levels described above. The second subset comprises genes Pc38,Pc39, Pc48, and $P c 68$, which are present in current Canadian commercial oat cultivars or important as sources of resistance in Canadian breeding programs. The third subset comprises genes $P c 51, P c 52, P c 58$, and $P c 59$, which are important as sources of resistance in the United States and, more recently, in eastern Canada. The fourth subset represents genes $P c 54, P c 56, P c 62$, and $P c 64$, which may have potential as sources of resistance in breeding programs or are important in differentiating $P$. coronata $\mathrm{f}$. sp. avenae populations in North America. For each subset of four differential hosts, there are 16 unique combinations of high and low infection types, arranged in a dichotomous system from all low to all high infection types (Table 3). An English letter code in alphabetic order from the 16 consonants (B through $\mathrm{T}$ ) was assigned to each of the 16 possible combinations of low and high infection types. The resulting fourletter code is used for $P$. coronata f. sp. avenae virulence phenotype designation.

Presently, more than 90 genes for crown rust resistance have been assigned with permanent designations (4). The proposed nomenclature system for $P$. coronata $\mathrm{f}$. $\mathrm{sp}$. avenae in North America thus does not provide a complete phenotypic description of avirulence and virulence, since only selected genes are used as primary differentials. However, the system is designed so

Table 3. Letter code designations for virulence phenotypes of Puccinia coronata $\mathrm{f}$. sp. avenae in North America, using 16 differential $P c$-gene Avena sativa lines, in ordered subsets of four differentials

\begin{tabular}{|c|c|c|c|c|c|}
\hline \multirow[b]{2}{*}{ Pca code ${ }^{\mathrm{b}}$} & \multirow[b]{2}{*}{$\begin{array}{l}P c \text { gene subset } 1 \\
P c \text { gene subset } 2 \\
P c \text { gene subset } 3 \\
P c \text { gene subset } 4\end{array}$} & \multicolumn{4}{|c|}{ Infection type $^{\text {a }}$ produced on single-gene $P c$ line } \\
\hline & & $\begin{array}{l}40 \\
38 \\
51 \\
54\end{array}$ & $\begin{array}{l}45 \\
39 \\
52 \\
56\end{array}$ & $\begin{array}{l}46 \\
48 \\
58 \\
62\end{array}$ & $\begin{array}{l}50 \\
68 \\
59 \\
64\end{array}$ \\
\hline B & & $\mathrm{L}$ & $\mathrm{L}$ & $\mathrm{L}$ & $\mathrm{L}$ \\
\hline $\mathrm{C}$ & & $\mathrm{L}$ & $\mathrm{L}$ & $\mathrm{L}$ & $\mathrm{H}$ \\
\hline D & & L & $\mathrm{L}$ & $\mathrm{H}$ & $\mathrm{L}$ \\
\hline $\mathrm{F}$ & & $\bar{L}$ & $\mathrm{~L}$ & $\mathrm{H}$ & $\mathrm{H}$ \\
\hline $\mathrm{G}$ & & L & $\mathrm{H}$ & $\mathrm{L}$ & $\mathrm{L}$ \\
\hline $\mathrm{H}$ & & $\mathrm{L}$ & $\mathrm{H}$ & $\mathrm{L}$ & $\mathrm{H}$ \\
\hline $\mathrm{J}$ & & $\mathrm{L}$ & $\mathrm{H}$ & $\mathrm{H}$ & $\mathrm{L}$ \\
\hline $\mathrm{K}$ & & $\mathrm{L}$ & $\mathrm{H}$ & $\mathrm{H}$ & $\mathrm{H}$ \\
\hline $\mathrm{L}$ & & $\mathrm{H}$ & $\mathrm{L}$ & $\mathrm{L}$ & $\mathrm{L}$ \\
\hline M & & $\mathrm{H}$ & $\mathrm{L}$ & $\mathrm{L}$ & $\mathrm{H}$ \\
\hline $\mathrm{N}$ & & $\mathrm{H}$ & $\mathrm{L}$ & $\mathrm{H}$ & $\mathrm{L}$ \\
\hline $\mathrm{P}$ & & $\mathrm{H}$ & $\mathrm{L}$ & $\mathrm{H}$ & $\mathrm{H}$ \\
\hline$Q$ & & $\mathrm{H}$ & $\mathrm{H}$ & $\mathrm{L}$ & $\mathrm{L}$ \\
\hline $\mathrm{R}$ & & $\mathrm{H}$ & $\mathrm{H}$ & $\mathrm{L}$ & $\mathrm{H}$ \\
\hline $\mathrm{S}$ & & $\mathrm{H}$ & $\mathrm{H}$ & $\mathrm{H}$ & $\mathrm{L}$ \\
\hline $\mathrm{T}$ & & $\mathrm{H}$ & $\mathrm{H}$ & $\mathrm{H}$ & $\mathrm{H}$ \\
\hline
\end{tabular}

${ }^{\mathrm{a}} \mathrm{L}=$ low infection type (avirulent reaction), $\mathrm{H}=$ high infection (virulent reaction).

${ }^{\mathrm{b}} \mathrm{Pca}$ code consists of the designation for subset 1 followed by that for subset 2, etc. For example, phenotype $\mathrm{LQBB}=$ subset $1(\mathrm{~L})$, virulent only to Pc40; subset $2(\mathrm{Q})$, virulent only to $P c 38,39$; subset 3 (B), avirulent to all four lines; subset 4 (B), avirulent to all four lines. that new differentials can be added to the set, because the letter code(s) for the new subset(s) can be added to the right of the existing four-letter code without affecting the previously used coding, e.g., LQBBG, where $\mathrm{G}$ is the additional letter code for the avirulence and virulence combination on the new subset of four differentials added to the right of the existing four-letter code LQBB. Because of local differences in pathogen virulence and host resistance, additional single-gene resistance lines may be used as supplemental differentials to permit evaluation of host genotypes of local interest. For this purpose, we propose that the virulence combination designation be reported with a four-letter code followed by a dash and an additional letter code describing the avirulence and virulence of the supplemental differential series. However, when less than four differentials are used in the supplemental series, virulence combination on these differentials for each isolate is described by a listing of the $P c$ gene(s) to which the isolate is virulent following the four-letter code and a dash, e.g., BQBB-Pc96 if the isolate is virulent only to Pc38 and Pc39 in the standard differential set (Table 3), and avirulent and virulent to the supplemental differentials, Pc94 and Pc96, respectively. Researchers should therefore indicate in their communication which additional host genes have been used as supplemental differentials to evaluate their isolate collection.

The $P$. coronata f. sp. avenae isolates from Canada and the United States used for illustrating the new nomenclature system in this study were obtained from the 1995 annual surveys in Canada (7) and the United States in 1995 (K. J. Leonard, unpublished). For Mexico (K. J. Leonard, unpublished), there were only seven isolates obtained from the survey in the state of Sonora in 1995. To make a larger, more representative sample, we included isolates from surveys in the states of Jalisco and Chihuahua in 1994 (J. Chong, unpublished; K. J. Leonard, unpublished).

\section{Application to Survey Data, 1995}

The frequency and geographic distribution of the $P$. coronata f. sp. avenae isolates virulent on the 16 host differentials in Canada and the United States in 1995 and in Mexico in 1994 and 1995 varied (Table 2). A total of 265 virulence phenotypes were identified from these isolates using the new nomenclature system; only the common virulence phenotypes found in the different regions in North America are shown in Table 4. Differences in the distribution of these common phenotypes were evident in the different regions (Table 4). The Ontario rust population was dominated by isolates with the $\mathrm{BQB}_{\text {- }}$ phenotypes due to selection for isolates with virulence to the Pc38 and Pc39 gene combination 
(Tables 2 and 3) (7). Many of these isolates were avirulent to host genes in subset 1 (Pc40, Pc45, Pc46, Pc50) and subset 3 (Pc51, Pc52, Pc58, Pc59) (Table 2). The most prevalent virulence phenotype was BQBB, at $30 \%$ of the isolates, followed by BQBG at $20 \%$ and BGBB at $6 \%$ (Table 4). In 1995, the Canadian prairie population was dominated by _Q_ _ phenotypes with virulence to $P c 38$ and $P c 39$, due to selection for isolates with this virulence (7), and many of these phenotypes were $\mathrm{DQ}_{-}$, $\mathrm{LQ}_{-}$, and NQ_ _ with virulence also to $P c 40$ and/or Pc46 (Tables 2 and 4) (7). The most common virulence phenotype was LQBB, at $14 \%$ of the isolates, followed by BQBB at $10 \%$ and LQLB at $6 \%$ (Table 4).

With few exceptions, populations of $P$. coronata f. sp. avenae from different regions of the United States, e.g., regions 1,
2 , and 3 in Table 2, were relatively similar in their avirulence and virulence to the host genes in the $P c a$ differential set. Compared with the $P$. coronata $\mathrm{f}$. sp. avenae population in the Canadian prairies, virulence frequencies throughout the United States were higher to Pc40,Pc46,Pc51, Pc59, $P c 54$, and $P c 56$ and lower to Pc38 and Pc39 (Table 2), due to prevalence of iso-

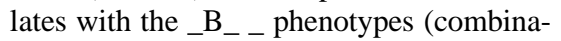
tions mainly of $\mathrm{LB}_{\__{-}}, \mathrm{PB}_{-}, \mathrm{MB}_{-}$, and/or $\mathrm{DB}_{-}{ }_{-}$) in the United States (not shown). Within the United States, regional differences in the distribution of the common virulence phenotypes were also evident in 1995 (Table 4). For example, the most common virulence phenotypes in Texas and Oklahoma (region 1 in Table 4) in 1995 were PBLB and PBLG at 13 and $12 \%$ of the isolates, respectively; whereas in Louisiana and Mississippi (region 2 in Table 4), the most common virulence phenotypes were LBMB and DBPB, at 16 and $8 \%$, respectively. In region 3 of Table 4 , which includes Alabama, Georgia, North Carolina, and Florida, the most common phenotypes in 1995 were LBMB at $14 \%$ and LBPB at 10\%; whereas the most common phenotype in the Ohio and Illinois region (region 5 in Table 4) was LBBB at $18 \%$. The $P$. coronata $\mathrm{f}$. sp. avenae population in the midwestern United States (region 6 in Table 4), which includes Minnesota, Iowa, North Dakota, and South Dakota, is the most diverse. Of the 92 virulence phenotypes identified in 1995 (not shown), none were found to occur at greater than 3\% (Table 4).

The Mexican P. coronata f. sp. avenae population, represented by isolates col-

Table 4. Frequency (\%) and distribution of selected virulence phenotypes ${ }^{\mathrm{a}}$ of Puccinia coronata f. sp. avenae in Canada and the United States in 1995 and in Mexico in 1994 and 1995

\begin{tabular}{|c|c|c|c|c|c|c|c|c|c|}
\hline \multirow{2}{*}{$\begin{array}{l}\text { Phenotype } \\
\text { code }^{\text {c }}\end{array}$} & \multirow{2}{*}{$\begin{array}{l}\text { Ineffective } \\
P c \text { genes }\end{array}$} & \multirow[b]{2}{*}{ Mexico } & \multicolumn{5}{|c|}{ United States $^{b}$} & \multicolumn{2}{|c|}{ Canada } \\
\hline & & & 1 & 2 & 3 & 5 & 6 & $\mathbf{M B} /$ SK $^{\mathbf{d}}$ & Ontario \\
\hline BGBB & 39 & & & & & & & & 6 \\
\hline BQBB & 38,39 & & & & & & 3 & 10 & 30 \\
\hline BQBD & $38,39,62$ & & & & & & & & 4 \\
\hline BQBG & $38,39,56$ & & & & & & & 2 & 20 \\
\hline BQLB & $38,39,51$ & & & & & & & 3 & \\
\hline DBBG & 46,56 & & & & & & 3 & & \\
\hline DBPB & $46,51,58,59$ & & & 8 & & & & & \\
\hline DLPB & $46,38,51,58,59$ & & & 5 & & & & & \\
\hline DQBB & $46,38,39$ & & & & & & & 5 & \\
\hline DQBG & $46,38,39,56$ & & & & & & & & 4 \\
\hline DQLB & $46,38,39,51$ & & & & & & & 2 & \\
\hline GBBB & 45 & 45 & & & & & & & \\
\hline GBBL & 45,54 & 6 & & & & & & & \\
\hline GBCL & $45,59,54$ & 9 & & & & & & & \\
\hline LBBB & 40 & & & & & 18 & & & \\
\hline LBCB & 40,59 & & & & & & & 2 & \\
\hline LBLB & 40,51 & & 8 & & & & & 2 & \\
\hline LBLG & $40,51,56$ & & 9 & & & & & & \\
\hline LBMB & $40,51,59$ & & & 16 & 14 & & & & \\
\hline LBMG & $40,51,59,56$ & & & & & & 3 & & \\
\hline LBML & $40,51,59,54$ & & & 7 & & & & & \\
\hline LBPB & $40,51,58,59$ & & & 5 & 10 & & 3 & & \\
\hline LQBB & $40,38,39$ & & & & & & 3 & 14 & \\
\hline LQCB & $40,38,39,59$ & & & & & & & 3 & \\
\hline LQLB & $40,38,39,51$ & & 3 & & & & 3 & 6 & \\
\hline LQMB & $40,38,39,51,59$ & & & & & & & 3 & \\
\hline MBBB & 40,50 & & & 7 & & & & & \\
\hline MBLB & $40,50,51$ & & 4 & & & & & & \\
\hline NBBG & $40,46,56$ & & & & & & 3 & & \\
\hline NBLG & $40,46,51,56$ & & & & & & 3 & & \\
\hline NQBB & $40,46,38,39$ & & & & & & & 4 & \\
\hline NQCB & $40,46,38,39,59$ & & 3 & & & & & & \\
\hline NQFB & $40,46,38,39,58,59$ & & 3 & & & & & & \\
\hline NQLB & $40,46,38,39,51$ & & & & & & & 2 & \\
\hline PBLB & $40,46,50,51$ & & 13 & & & & & & \\
\hline PBLG & $40,46,50,51,56$ & & 12 & & & & & & \\
\hline No. of isolates ${ }^{\mathrm{e}}$ & & 47 & 100 & 76 & 29 & 17 & 119 & 189 & 71 \\
\hline $\begin{array}{l}\text { No. of virulence } \\
\text { phenotypes }^{\text {f }}\end{array}$ & & 19 & 48 & 45 & 19 & 15 & 92 & 83 & 25 \\
\hline $\begin{array}{l}\text { a Virulence phen } \\
\text { b Region } 1=\text { Tex } \\
\text { 6, Minnesota, I } \\
1995 . \\
\text { c Based on } 16 \text { di } \\
\text { 56, 62, 64). } \\
\text { d Manitoba and e } \\
\text { e Total number o } \\
\text { f }\end{array}$ & $\begin{array}{l}\text { Ok North Dakota, Sou } \\
\text { entials arranged in fo } \\
\text { ern Saskatchewan. } \\
\text { olates established fro }\end{array}$ & $\begin{array}{l}\text { ee times i } \\
\text { uisiana, } \\
\text { kota. Reg } \\
\text { bsets (sub } \\
\text { ch region }\end{array}$ & $\begin{array}{l}\text { regio } \\
\text { ippi; } 1 \\
\text { (Mass } \\
=P c 4 \\
\text { eyear }\end{array}$ & $\begin{array}{l}=\text { Ala } \\
\text { s, Pen } \\
50\end{array}$ & $=P c$ & $\begin{array}{l}\text {, No } \\
\text { ed be } \\
, 68\end{array}$ & $\begin{array}{l}\text { lina; } \\
1 \text { pher } \\
=P c\end{array}$ & $\begin{array}{l}5=\text { Ohio, } \\
\text { es were fou } \\
2,58,59\end{array}$ & $\begin{array}{l}\text { inois; regio } \\
\text { only once i } \\
\text { et } 4=P c 5\end{array}$ \\
\hline
\end{tabular}


lected from Chihuahua and Jalisco in 1994 and Sonora in 1995, differed in virulence from populations in other regions in North America (Tables 2 and 4). Virulence to Pc45 was $89 \%$ in Mexico, while virulence to this gene was generally below $10 \%$ elsewhere in North America (Table 2). The high virulence frequency to $P c 45$ was attributed to the prevalence of isolates having the $\mathrm{GB}_{-}{ }_{-}(72.4 \%)$ and $\mathrm{JB}_{-}$- $(10.6 \%)$ virulence combinations (J. Chong, unpublished; K. J. Leonard, unpublished). During the 1994 to 1995 period, the most common virulence phenotype was $\mathrm{GBBB}$, at $45 \%$ of the isolates, followed by GBCL at $9 \%$ and GBBL at $6 \%$ (Table 4). These three phenotypes were similar with respect to virulence to $P c 45$, except that GBBL had additional virulence to Pc54, and GBCL had additional virulence to $P c 54$ and $P c 59$.

\section{Discussion}

In North America, P. coronata f. sp. avenae is highly diverse in virulence phenotypes (7; K. J. Leonard, unpublished). Introduction of resistance genes in host populations has been followed by an increase in the corresponding virulence in the rust population, rendering the resistance ineffective $(5,7,34)$. The trend of increasing diversity in the $P$. coronata $\mathrm{f}$. sp. avenae populations will likely continue as more genes are used for host resistance $(5,7,22)$. Future changes in rust populations will necessitate changes in the host differentials to maintain the relevancy of virulence phenotype determination. Ineffective differentials can be replaced with new ones, as the proposed system permits virulence phenotype designations to be assigned to avirulence and virulence combinations directly without having the need to contact a central source. However, changes to the $P c a$ set should be infrequent and made only when necessary (e.g., when differentials become ineffective). For the purpose of communication among researchers, the current $P c a$ set should be designated with the year attached ( $\mathrm{PCa}$ $2000)$ to distinguish it from future differential sets.

The characterization of virulence in $P$. coronata $\mathrm{f}$. $\mathrm{sp}$. avenae populations on a global basis has been difficult due to differences in host differentials and the nomenclature system used. This is because researchers gradually adopted local sets of differentials that could better reflect their needs due to regional differences in pathogen virulence and host resistance. In Europe and Israel, avirulence-virulence formulae (15) generally have been used for designating $P$. coronata $\mathrm{f}$. sp. avenae virulence phenotypes $(8,23,26,33,38)$. Recently, a separate system based on coded triplet values (24) has been developed for designating virulence phenotypes in Australia (2). Many of the host genes (up to 16) proposed for the present North American Pca-2000 set also have been adopted for use as differentials at various times in Europe $(8,23,33,38)$ and in Australia (2). Despite differences in nomenclature between North America and other continents, the continued use of these differentials will serve as links for communication among researchers for $P$. coronata $\mathrm{f}$. $\mathrm{sp}$. avenae virulence on a worldwide basis.

Previous studies indicated that $P$. coronata f. sp. avenae reproduces mainly sexually in Ontario and in the Canadian prairie region $(5,22)$. This is clearly the case with the rust populations in the midwestern United States, since Rhamnus cathartica, the alternate host, is abundant and widespread (K. J. Leonard, unpublished). Sexually reproducing populations are more diverse because of reassortment of virulences (32). Associations of virulences (linkage disequilibria) are rare in these populations, as shown in the Canadian $P$. coronata f. sp. avenae populations (22); whereas in wholly asexual populations, virulences are effectively linked (linkage disequilibria) in more stable populations that may persist for years as in $P$. graminis f. sp. tritici (1). Virulence phenotype designations may become less useful in sexually reproducing populations, as many different virulence phenotypes are generated every year. However, $P$. coronata $\mathrm{f}$. sp. avenae is not necessarily sexual over its entire range in North America, as there is little evidence to indicate that aecia play any significant role in overwintering of the fungus in Mexico and in California and southern parts (e.g., Kansas, Texas) of the United States. Our finding that $45 \%$ of the isolates from Mexico were GBBB, 25\% of the isolates from Texas and Oklahoma were either PBLB or PBLG (Table 4), and 31 to $41 \%$ of the isolates were $\mathrm{LB}_{-}$- $_{-}$in regions 2, 3, and 5 of the United States (only the more common phenotypes of these were shown in Table 4) further illustrates the point that crown rust virulences are not in linkage equilibrium everywhere in North America. The new nomenclature system provides a handy shorthand way to identify and follow specific virulence phenotypes that recur.

The identification of virulence phenotypes has been and will continue to be an integral part of breeding programs to develop resistant host cultivars. Also, the identification of virulence phenotypes will be useful for studying regional disease spread and for determining regional differences in virulence for the purpose of gene deployment in North America. Given the degree of virulence diversity in $P$. coronata f. sp. avenae and the large number of host genes being used as differentials, the proposed $P c a$ nomenclature will help to condense the avirulence-virulence formulae into more concise four-letter codes for easier communication. The previous use of avirulence-virulence formula made it difficult to follow trends in populations of $P$. coronata f. sp. avenae that are highly com- plex and diverse for virulence patterns. The proposed new system should simplify the designation of important virulence combinations, and also should facilitate the study of selection of virulences in the oat crown rust populations.

\section{ACKNOWLEDGMENTS}

We thank J. Stebbing and G. Ochocki for technical assistance.

\section{LITERATURE CITED}

1. Alexander, H. M., Roelfs, A. P., and Groth, J. V. 1984. Pathogenicity associations in Puccinia graminis f. sp. tritici in the United States. Phytopathology 74:1161-1166.

2. Bonnett, D. G. B. 1996. Host : pathogen studies of oat leaf rust in Australia. Ph.D. diss. University of Sydney, Sydney, Australia.

3. Browning, J. A., Simons, M. D., Farey, K. J., and Murphy, H. C. 1969. Regional deployment for conservation of oat crown rust resistance genes. Ia. Agric. Home Econ. Exp. Stn. J. Pap. J6261. pp. 49-56.

4. Chong, J., and Brown, P. D. 1996. Genetics of resistance to Puccinia coronata f. sp. avenae in two Avena sativa accessions. Can. J. Plant Pathol. 18:286-292.

5. Chong, J., and Kolmer, J. A. 1993. Virulence dynamics and phenotypic diversity of Puccinia coronata $\mathrm{f}$. $\mathrm{sp}$. avenae in Canada from 1974 to 1990 . Can. J. Bot. 71:248-255.

6. Chong, J., and Seaman, W. L. 1990. Distribution and virulence of Puccinia coronata in Canada in 1990. Can. J. Plant Pathol. 12:431435.

7. Chong, J., and Seaman, W. L. 1997. Incidence and virulence of Puccinia coronata $\mathrm{f}$. sp. ave nae in Canada in 1995. Can. J. Plant Pathol. 19:176-180.

8. Dobrev, D., and Antonova, N. 1995. Genetical differentiation of oat crown rust in relation to selection for rust resistance. Petria 5:66-67.

9. Fleischmann, G., and Baker, R. J. 1971. Oat crown rust race differentiation: Replacement of the standard differential varieties with a new set of single resistance gene lines derived from Avena sterilis. Can. J. Bot. 49:14331437.

10. Fleischmann, G., and McKenzie, R. I. H 1968. Inheritance of crown rust resistance in Avena sterilis. Crop Sci. 8:710-713.

11. Fleischmann, G., McKenzie, R. I. H., and Shipton, W. A. 1971. Inheritance of crown rust resistance in Avena sterilis L. from Israel. Crop Sci. 11:451-453.

12. Fleischmann, G., McKenzie, R. I. H., and Shipton, W. A. 1971. Inheritance of crown rust resistance genes in Avena sterilis collections from Israel, Portugal, and Tunisia. Can J. Genet. Cytol. 13:251-255.

13. Frey, K. J., Browning, J. A., and Grindeland, R. L. 1971. Registration of Multiline E68, Multiline M69, and Multiline E70 oat cultivars. Crop Sci. 11:939-940.

14. Frey, K. J., Browning, J. A., and Grindeland, R. L. 1971. Registration of Multiline M68, Multiline M69, and Multiline M70 oat cultivars. Crop Sci. 11:940-941.

15. Green, G. J. 1965. Stem rust of wheat, rye, and barley in Canada in 1965. Can. Plant Dis. Surv. 45:23-29.

16. Harder, D. E. 1975. Crown rust of oats in Canada in 1974. Can. Plant Dis. Surv. 55:6365.

17. Harder, D. E. 1980. Virulence and distribution of Puccinia coronata avenae in Canada in 1979. Can. J. Plant Pathol. 2:249-252.

18. Harder, D. E., and Chong, J. 1983. Virulence and distribution of Puccinia coronata in Canada in 1982. Can. J. Plant Pathol. 5:185-188.

19. Harder, D. E., McKenzie, R. I. H., and Mar- 
tens, J. W. 1980. Inheritance of crown rust resistance in three accessions of Avena sterilis. Can. J. Genet. Cytol. 22:27-33.

20. Hoerner, G. R. 1919. Biologic forms of Puccinia coronata on oats. Phytopathology 9:309-314.

21. Kiehn, F. A., McKenzie, R. I. H., and Harder, D. E. 1976. Inheritance of resistance to Puccinia coronata avenae and its association with seed characteristics in four accessions of Avena sterilis. Can. J. Genet. Cytol. 18:717-726.

22. Kolmer, J. A., and Chong, J. 1993. Distribution of virulence in two populations of Puccinia coronata $\mathrm{f}$. sp. avenae in Canada. Can. J. Bot. 71:946-950.

23. Leijerstam, B. 1995. The virulence spectrum of oat crown rust, Puccinia coronata f. sp. avenae in Sweden. Sver. Utsadesforenings Tidskrift. 105:53-58.

24. Limpert, E., and Muller, K. 1994. Designations of Pathotypes of Plant Pathogens. J. Phytopathol. 140:346-358.

25. Long, D. L., and Kolmer, J. A. 1989. A North American system of nomenclature for Puccinia recondita $\mathrm{f}$. sp. tritici. Phytopathology 79:525-529.

26. Manisterski, J., and Wahl, I. 1995. Studies on oat crown rust in Israel. Petria 5:50-54.

27. Martens, J. W., McKenzie, R. I. H., and Harder, D. E. 1980. Resistance to Puccinia graminis avenae and $P$. coronata avenae in the wild and cultivated Avena populations of Iran, Iraq and Turkey. Can. J. Genet. Cytol. 22:641-649.

28. Murphy, H. C. 1935. Physiologic specialization in Puccinia coronata avenae. U.S. Dep. Agric. Tech. Bull. 433.

29. Parson, H. E. 1927. Physiologic specialization in Puccinia coronata avenae. Phytopathology 27:783-790.

30. Peturson, B. 1935. Physiologic specialization in Puccinia coronata avenae. Sci. Agric. 15:806-810.

31. Popp, W. 1926. Crown rust of oats in Eastern Canada. Annu. Rep. Que. Soc. Prot. Plants. 18:383-453.

32. Roelfs, A. P., and Martens, J. W. 1988. An international system of nomenclature for Puccinia graminis f. sp. tritici. Phytopathology 78:526-533.

33. Sebesta, J., Zwatz, B., Harder, D. E., Corazza, L., and Stojanovic, S. 1997. Incidence of crown rust and virulence of Puccinia coro$n a t a$ on oat and the effectiveness of $P c$-genes for resistance in Europe during 1990-1994. Arch. Phytopathol. Pflanz. 30:507-518.

34. Simons, M. D. 1985. Crown rust. Pages 131172 in: The Cereal Rusts. Vol. II, Diseases, Distribution, Epidemiology and Control. A. P Roelfs and W. R. Bushnell, eds. Academic Press, Orlando, FL.

35. Simons, M. D., Martens, J. W., McKenzie, R. I. H., Nishiyama, I., Sadanaga, K., Sebesta, J. and Thomas, H. 1978. Oats: A standardized system of nomenclature for genes and chromosomes and catalog of genes governing characters. U.S. Dep. Agric. Agric. Handb. 509.

36. Simons, M. D., and Murphy, H. 1955. A comparison of certain combinations of oat varieties as crown rust differentials. U.S. Dep. Agric. Tech. Bull. 1112:1-22.

37. Wong, L. S. L., McKenzie, R. I. H., Harder, D. E., and Martens, J. W. 1983. The inheritance of resistance to Puccinia coronata and of floret characters in Avena sterilis. Can. J. Genet. Cytol. 25:329-335.

38. Yuhnina, E. K., Lyzlov, E. V., and Pugatcheva, G. T. 1995. Characterization of Puccinia coronata var. avenae population in Moscow region. Petria 5:70-71. 